\title{
Activation of Spinal $\mu$ - and $\delta$-0pioid Receptors Potently Inhibits Substance P Release Induced by Peripheral Noxious Stimuli
}

\author{
Hélène Beaudry, ${ }^{1}$ Dave Dubois, ${ }^{1}$ and Louis Gendron ${ }^{1,2}$ \\ ${ }^{1}$ Département de Physiologie et Biophysique, Faculté de Médecine et des Sciences de la Santé, and ${ }^{2}$ Institut de Pharmacologie de Sherbrooke, Université de \\ Sherbrooke, Sherbrooke, Québec J1H 5N4, Canada
}

Over the past few years, $\delta$-opioid receptors (DOPRs) and $\mu$-opioid receptors (MOPRs) have been shown to interact with each other. We have previously seen that expression of MOPR is essential for morphine and inflammation to potentiate the analgesic properties of selective DOPR agonists. In vivo, it is not clear whether MOPRs and DOPRs are expressed in the same neurons. Indeed, it was recently proposed that these receptors are segregated in different populations of nociceptors, with MOPRs and DOPRs expressed by peptidergic and nonpeptidergic fibers, respectively. In the present study, the role and the effects of DOPR- and MOPR-selective agonists in two different pain models were compared. Using preprotachykinin A knock-out mice, we first confirmed that substance P partly mediates intraplantar formalin- and capsaicin-induced pain behaviors. These mice had a significant reduction in pain behavior compared with wild-type mice. We then measured the effects of intrathecal deltorphin II (DOPR agonist) and DAMGO (MOPR agonist) on pain-like behavior, neuronal activation, and substance P release following formalin and capsaicin injection. We found that both agonists were able to decrease formalin- and capsaicin-induced pain, an effect that was correlated with a reduction in the number of c-fos-positive neurons in the superficial laminae of the lumbar spinal cord. Finally, visualization of $\mathrm{NK}_{1}$ (neurokinin 1 ) receptor internalization revealed that DOPR and MOPR activation strongly reduced formalin- and capsaicin-induced substance P release via direct action on primary afferent fibers. Together, our results indicate that functional MOPRs and DOPRs are both expressed by peptidergic nociceptors.

\section{Introduction}

Over the past few years, we have described an essential role for the $\mu$-opioid receptor (MOPR) in regulating the surface density of the $\delta$-opioid receptors (DOPRs) as well as the analgesic properties of DOPR agonists (Cahill et al., 2001; Morinville et al., 2003, 2004a; Gendron et al., 2006, 2007b). This essential role for MOPR in the emergence of the functions of DOPR was also described by others (Hack et al., 2005; Ma et al., 2006). Different hypothesis have been raised to explain the cellular mechanisms involved in this phenomenon (Zhang et al., 2006; Cahill et al., 2007). In particular, a role for substance P (SP) and its precursor was described previously (Guan et al., 2005). Among other putative

\footnotetext{
Received April 10, 2011; revised July 12, 2011; accepted July 21, 2011

Author contributions: H.B. and L.G. designed research; H.B., D.D., and L.G. performed research; H.B. and L.G. analyzed data; H.B. and L.G. wrote the paper.

This work was supported by Canadian Institutes of Health Research (CIHR) Grant MOP-84538 (L.G.). L.G. is the recipient of a Fonds de la Recherche en Santé du Québec (FRSQ) Junior 1 salary support. H.B. is the recipient of a scholarship from the Alexander Graham Bell Canada Graduate Scholarships Program awarded by the Natural Sciences and Engineering Research Council of Canada and of a doctoral scholarship from the FRSQ. D.D. is the recipient of a scholarship from the Frederick Banting and Charles Best Canada Graduate Scholarships-Master's Award awarded by the CIHR. We are thankful to Julie Desroches for providing technical assistance with behavioral experiments. We are also grateful to Robert Dumaine and Philippe Sarret for granting access to the Olympus confocal microscope funded by the Canadian Foundation for Innovation.

Correspondence should be addressed to Dr. Louis Gendron, Département de Physiologie et Biophysique, Université de Sherbrooke, Faculté de Médecine et des Sciences de la Santé, Sherbrooke, Québec J1H 5N4, Canada. E-mail: louis.gendron@usherbrooke.ca.

DOI:10.1523/JNEUROSCI.1817-11.2011

Copyright $\odot 2011$ the authors $\quad 0270-6474 / 11 / 3113068-10 \$ 15.00 / 0$
}

mechanisms, a physical interaction between MOPR and DOPR was proposed. However, whether or not these receptors are expressed in the same cells or even in the same subset of neurons is still unclear and controversial.

It is well known that MOPRs are expressed on substance P-containing primary afferents. However, expression of DOPRs by these neurons has recently been challenged. Indeed, using mice expressing an enhanced green fluorescent protein (eGFP)tagged DOPR (eGFP-DOPR knockin mice), Scherrer et al. (2009) recently showed that MOPR and DOPR rarely colocalize in dorsal root ganglia (DRGs) neurons (Scherrer et al., 2009). In these mice, they confirmed that MOPRs were expressed on small, peptidergic C-fibers but found that DOPRs were preferentially localized on medium-sized, nonpeptidergic primary afferents and on large, myelinated neurons (Scherrer et al., 2009). If this segregation of MOPR and DOPR in primary afferents are not an artifact purely caused by the large eGFP fusion protein, which was shown to interfere with expression, trafficking, and functions of DOPR (Wang et al., 2008) as well as other receptors (McLean and Milligan, 2000; Madziva and Edwardson, 2001; McDonald et al., 2007; Roy et al., 2007), then it would have a tremendous impact because it implies that endogenous MOPR and DOPR cannot physically interact and dimerize to influence each other (for review, see van Rijn et al., 2010). Even more significant for drug development, it raises the hypothesis that selective agonists of these receptors might affect different pain modalities. Indeed, it was proposed that spinal DOPR activation only inhibits mechan- 
ical pain while MOPR activation inhibits thermal pain (Scherrer et al., 2009).

As the specificity of most commercial DOPR antibodies often used for immunohistochemical labeling experiments were also questioned (Scherrer et al., 2009), it becomes necessary to clearly establish whether DOPR and MOPR could play similar roles for pain relief and if they are expressed by the same subset of neurons. Although mainly relying on DOPR antibodies, various studies suggest that MOPR and DOPR are both expressed on SPcontaining, unmyelinated nociceptors (Minami et al., 1995; Wang et al., 2010). We therefore formed the hypothesis that MOPR and DOPR agonists could modulate the activity of these neurons in a similar fashion. In the present study, we used a combination of behavioral tests, immunolabeling, and measurement of SP release [by visualizing neurokinin $1\left(\mathrm{NK}_{1}\right)$ receptor internalization] in rats to assess and compare the ability of intrathecal deltorphin II (DOPR-selective agonist) and DAMGO (MOPR-selective agonist) to inhibit pain-like behaviors and neuronal activation induced by intradermal formalin and intraplantar capsaicin.

\section{Materials and Methods}

Animals. Preprotachykinin A (PPTA) knock-out male (-/-; Tac1 ${ }^{\text {Tm1Bbm; }}$ The Jackson Laboratory) and wild-type female $(+/+$; Charles River) mice were used to establish the colony as described previously (Dubois and Gendron, 2010). An $\mathrm{F}_{1}$ generation of heterozygous (+/-) mice was used to produce $\mathrm{F}_{2}$ PPTA $^{-1-}$ and PPTA ${ }^{+/+}$littermates, which were then used in our experiments. Mice were genotyped using DNA extract from tail samples. Mice were housed in groups of two to four and maintained on a $14 \mathrm{~h} \mathrm{light/}$ dark cycle (6:00 A.M. to 8:00 P.M.). Laboratory chow and water were available ad libitum. Adult male Sprague Dawley rats (200-240 g; Charles River) were maintained on a $12 \mathrm{~h}$ light/dark cycle (6:00 A.M. to 6:00 P.M.). All studies were conducted between 7:00 A.M. and 12:00 P.M. (light cycle). Experiments were approved by the animal care committee of the Universite de Sherbrooke (protocol no. 242-10 for rats and nos. 080-06 and 242-10 for mice) in compliance with the policies and directives of the Canadian Council on Animal Care and guidelines from the International Association for the Study of Pain. Experiments were designed to minimize the number of animals used and their suffering.

Drugs. Deltorphin II (Dlt II) (American Peptide; lot no. M08048T1), a peptidic DOPR-selective agonist, was dissolved in sterile saline solution and injected intrathecally ( 10 or $30 \mu \mathrm{g}$ in $30 \mu \mathrm{l}$; corresponding to 12.7 and $38.1 \mathrm{nmol}$, respectively). DAMGO (Tocris), a MOPR-selective agonist, was diluted in sterile saline and injected intrathecally ( 1 or $10 \mu \mathrm{g}$ in $30 \mu \mathrm{l}$; corresponding to 1.9 and $19.4 \mathrm{nmol}$, respectively). To ascertain drug selectivity, naltrindole (NTI) (50 or $150 \mathrm{nmol}$; Tocris) and D-PheCys-Tyr-D-Trp-Orn-Thr-Pen-Thr- $\mathrm{NH}_{2}$ (CTOP) (6 or $30 \mathrm{nmol}$; Tocris) were used as DOPR- and MOPR-selective antagonists, respectively. They were coinjected or injected $5 \mathrm{~min}$ before agonists. SP ( $22 \mathrm{nmol}$ in $30 \mu \mathrm{l}$; Sigma-Aldrich) was also dissolved in sterile saline solution. The control vehicle used for all experiments was intrathecal saline.

In all experiments, Dlt II and DAMGO were injected intrathecally 5 min before intraplantar formalin or capsaicin injection or intrathecal SP injection. Injections were administered to nonanesthetized rats because a pilot study from our laboratory revealed that isoflurane anesthesia modified capsaicin-induced pain behavior (data not shown). This is consistent with recent data showing a direct effect of general anesthetics on TRP channels. Indeed, isoflurane was shown to modulate capsaicin-evoked TRPV1 currents (Cornett et al., 2008; Matta et al., 2008). For both mice and rats, we used a technique previously described (Fairbanks, 2003) with a $>95 \%$ success rate. Briefly, a 30 ga half-inch needle mounted on a Luer tip Hamilton syringe (VWR) was inserted into the L5-L6 intervertebral space (at the level of the cauda equina), and drugs were injected over a $2 \mathrm{~s}$ period of time. Appropriate placement of the needle was confirmed by observing a brief twitch of the tail.

Formalin test. Antinociception was assessed using the formalin test as a model of tonic pain. Briefly, 5 min after they received intrathecal injec- tion of the drug or the vehicle, rats were injected intradermally with $50 \mu \mathrm{l}$ of a $2 \%$ formaldehyde solution (i.e., $5.4 \%$ formalin; Thermo Fisher Scientific) or $50 \mu \mathrm{l}$ of saline (control) into the plantar surface of the left hindpaw. A volume of $10 \mu \mathrm{l}$ of the same solution was used for mice. Animals were then immediately placed in a clear plastic chamber $(30 \times$ $30 \times 30 \mathrm{~cm}$ ) positioned over a mirror angled at $45^{\circ}$ to allow for an unobstructed view of the paws. Their behaviors were then observed for the next $60 \mathrm{~min}$. Intradermal injection of formalin produces a biphasic nociceptive response typical of this tonic pain model (Tjølsen et al., 1992; Coderre et al., 1993). Nocifensive behaviors were assessed using a weighted score, as described previously (Dubuisson and Dennis, 1977; Coderre et al., 1993). Nociceptive mean score was determined for each 3 min block during the recording period by measuring the amount of time spent in each of four behavioral categories: 0 , the injected paw is comparable with the contralateral paw and is used normally by the animal; 1 , the injected paw has little or no weight placed on it; 2 , the injected paw is elevated and is not in contact with any surface; and 3, the injected paw is licked, bitten, or flinched. The weighted nociceptive score ranged from 0 to 3 and was calculated by multiplying the time (in seconds) spent in each category by its assigned category weight, summing these products and dividing by the total time for each 3 min block of time: Pain rating $=(1 \mathrm{~T} 1+2 \mathrm{~T} 2+3 \mathrm{~T} 3) / 180$. The total area under the curve (AUC) was also calculated for each animal.

Capsaicin test. Antinociception was also assessed with capsaicin as a model of thermal pain. For this purpose, $5 \mathrm{~min}$ after they received intrathecal injection of the drug or the vehicle, rats were injected subcutaneously with $50 \mu \mathrm{l}$ of a capsaicin solution (i.e., $10 \mu \mathrm{g}$ of capsaicin with $20 \%$ ethanol and 7\% Tween 80 in sterile saline solution) or vehicle solution (20\% ethanol and $7 \%$ Tween 80 in sterile saline) into the plantar surface of the left hindpaw. Mice received $6 \mu \mathrm{g}$ of capsaicin in a total volume of $10 \mu \mathrm{l}$. Animals were observed and their pain behaviors were evaluated as described above for the formalin test.

$c$-fos expression. Sixty minutes after formalin or capsaicin injection, rats were deeply anesthetized and killed by intra-aortic arch perfusion of $4 \%$ paraformaldehyde (PFA) in $500 \mathrm{ml}$ of $0.1 \mathrm{~m}$ phosphate buffer (PB), $\mathrm{pH} \mathrm{7.4}$, at $4^{\circ} \mathrm{C}$, postfixed for $2 \mathrm{~h}$ at $4^{\circ} \mathrm{C}$ and incubated in $30 \%$ sucrose in $0.2 \mathrm{M}$ PB for $48 \mathrm{~h}$. The lumbar segment of the spinal cord was snap frozen in isopentane at $-45^{\circ} \mathrm{C}$ and stored at $-80^{\circ} \mathrm{C}$ until sectioning. Tissues were sectioned on a microtome at a thickness of $30 \mu \mathrm{m}$, and immunohistochemistry against c-fos was performed. Briefly, free-floating sections were washed in PBS and then treated with $1 \%$ hydrogen peroxide. Sections were then incubated in primary antibody solution containing $0.3 \%$ Triton X-100, 3\% goat serum in PBS, and 1:20,000 anti-c-Fos (Santa Cruz; sc-52) for $18 \mathrm{~h}$ at $4^{\circ} \mathrm{C}$. Sections were then washed in PBS and incubated with a biotinylated goat anti-rabbit secondary antibody at 1:400 in PBS for $60 \mathrm{~min}$ at room temperature. Sections were then treated using the $\mathrm{ABC}$ system (Vector) and stained using diaminobenzidine and nickel (Sigma-Aldrich).

After dehydration, sections were photographed using a bright-field microscope (Leica DM4000B; Leica Microsystems) equipped with an InfinityX camera (Lumenera). For the quantification of c-fos-labeled neurons, each section of the spinal cord was divided into three regions of interest: laminae I-II, laminae III-IV, and laminae V-VI according to the structure of the spinal cord (Molander et al., 1984), by applying a template over each of the micrographs. The number of c-fosimmunoreactive neurons in the three defined regions was determined by a blinded observer by averaging the counts made in $8-10$ sections per animal from three independent experiments and expressed as the mean \pm SEM.

$N K_{1}$ receptor internalization. Ten minutes after injection of formalin, capsaicin, or SP, animals were deeply anesthetized and killed by intraaortic arch perfusion of $4 \%$ PFA with $0.18 \%$ picric acid in $0.1 \mathrm{M} \mathrm{PB}, \mathrm{pH}$ 7.4 , at $4^{\circ} \mathrm{C}(500 \mathrm{ml})$, postfixed in the same solution for $1 \mathrm{~h}$ at $4^{\circ} \mathrm{C}$, and incubated in $30 \%$ sucrose in $0.2 \mathrm{M} \mathrm{PB}$ for $48 \mathrm{~h}$. The lumbar segment of the spinal cord was snap frozen in isopentane at $-45^{\circ} \mathrm{C}$ and stored at $-80^{\circ} \mathrm{C}$ until sectioning. Tissues were sectioned on a microtome at a thickness of $30 \mu \mathrm{m}$, and immunofluorescence labeling of $\mathrm{NK}_{1}$ receptor $\left(\mathrm{NK}_{1} \mathrm{R}\right)$ was performed. Briefly, free-floating sections were washed in PBS and then treated with $1 \%$ sodium borohydride during $30 \mathrm{~min}$ to quench autofluorescence produced by unreacted aldehydes and thoroughly rinsed. Sec- 
tions were then incubated in primary antibody solution containing $0.3 \%$ Triton X-100 and 3\% goat serum in PBS with anti-NK $\mathrm{NK}_{1} \mathrm{R}(1: 5000)$ (Sigma-Aldrich) for $24 \mathrm{~h}$ at $4^{\circ} \mathrm{C}$. Sections were then washed in PBS and incubated with a goat anti-rabbit secondary antibody coupled to Alexa Fluor 488 (Invitrogen) at a concentration of 1:1000 in PBS for $60 \mathrm{~min}$ at room temperature.

Images were collected on an Olympus Fluoview 1000 (FV1000) laserscanning confocal microscope (Olympus) built around an IX81-ZDC inverted microscope fitted with a U Plan S-Apo $60 \times(1.35 \mathrm{NA})$ oilimmersion objective. The amount of $\mathrm{NK}_{1} \mathrm{R}$ internalization was quantified using a method described by others (Mantyh et al., 1995; Abbadie et al., 1997; Honor et al., 1999; Kondo et al., 2005). This method relies on using an epifluorescence microscope (Leica DM4000B; Leica Microsystems) to count $\mathrm{NK}_{1} \mathrm{R}$-immunoreactive neurons in lamina $\mathrm{I}$, with and without $\mathrm{NK}_{1} \mathrm{R}$ internalization, and using this to calculate the percentage of $\mathrm{NK}_{1} \mathrm{R}$-positive neurons with internalization. The number of neurons with $\mathrm{NK}_{1} \mathrm{R}$ internalization was determined by averaging the counts made in three animals per condition with 15-18 sections per animal, and results were expressed as the mean \pm SEM. The observer was blinded to the treatment throughout the counting process.

Calculations and statistical analysis. Calculations were done with Excel 2007; graphs, with SigmaPlot 11.0; and statistical analysis was performed with Prism GraphPad 5.1. Data are expressed as the mean \pm SEM. Values of $p$ are presented in the figure legends.

\section{Results}

Formalin- and capsaicin-induced pain behaviors in PPTA knock-out mice

Injection of formalin and capsaicin into the hindpaw induces the release of diverse excitatory neurotransmitters from primary afferent endings located in the dorsal horn of the lumbar spinal cord (Bucsics and Lembeck, 1981; Kantner et al., 1986). To evaluate the contribution of SP to formalin- and capsaicin-evoked pain behaviors, we compared the effects of formalin and capsaicin in $\mathrm{PPTA}^{+/+}$and PPTA ${ }^{-1-}$ mice. In the $\mathrm{PPTA}^{-1-}$ mice, we and others have shown the absence of SP-like labeling in the spinal cord (Cao et al., 1998; Dubois and Gendron, 2010). In the present study, we observed that, for both genotypes, intradermal formalin injection produced a biphasic nociceptive response (Fig. 1 $A$, inset), whereas capsaicin-induced pain behavior remained constant over more than an hour (Fig. $1 B$, inset). The pain scores measured over the first 15 min following injection of formalin and capsaicin to $\mathrm{PPTA}^{+/+}$and $\mathrm{PPTA}^{-/-}$mice are shown in Figure 1, $A$ and $B$, respectively. As revealed by the AUCs, absence of SP in PPTA ${ }^{-1-}$ mice induced a significant decrease in pain evoked by formalin (AUC, $20.6 \pm 0.2$ vs $18.3 \pm 0.7$ for PPTA $^{+/+}$and PPTA ${ }^{-/-}$, respectively; $p=0.0132, t=3.008$ and $\mathrm{df}=10$, unpaired $t$ test) and capsaicin during the first $15 \mathrm{~min}$ (AUC, $17.2 \pm 1.6$ vs $10.0 \pm 0.7$ for PPTA $^{+/+}$and PPTA ${ }^{-/-}$, respectively; $p=0.0033, t=4.132$ and $\mathrm{df}=8$, unpaired $t$ test). When formalin- and capsaicin-induced pain behaviors were analyzed over a longer period of time (Fig. $1 A, B$, insets), no further difference was observed between the genotypes. These results suggest that SP release is involved, at least to a certain extent, in the early steps of formalin- and capsaicin-induced pain behaviors and that PPTA invalidation reduced these behaviors.

\section{Inhibition of formalin-induced pain behaviors following activation of DOPR and MOPR}

In Sprague Dawley rats, intradermal injection of formalin produced a biphasic nociceptive response that is typical of this tonic pain model (Fig. $2 A, B$ ). Intradermal injection of the vehicle had no effect (Fig. 2A). Intrathecal injection of Dlt II (10 $\mu \mathrm{g}) 5 \mathrm{~min}$ before formalin strongly reduced the total pain score seen in the test. This effect was also observed when only the first $15 \mathrm{~min}$ of

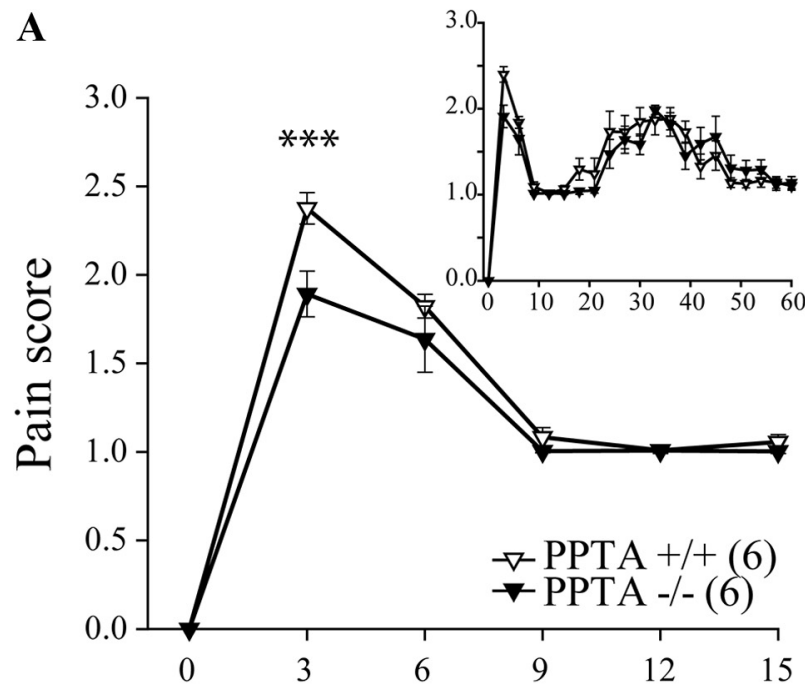

\section{Time after formalin injection (min)}

B

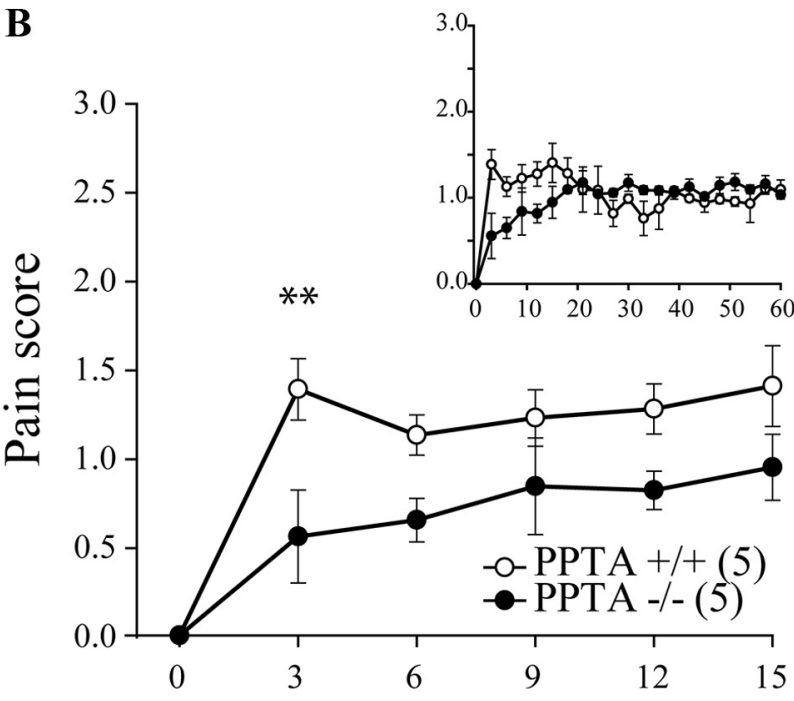

\section{Time after capsaicin injection (min)}

Figure 1. Formalin- and capsaicin-induced pain behaviors in PPTA ${ }^{-1-}$ mice. PPTA ${ }^{-1-}$ and their PPTA ${ }^{+1+}$ littermates were injected with formalin or capsaicin in the plantar surface of the hindpaw, and their pain behaviors were observed for $60 \mathrm{~min}(\boldsymbol{A}, \boldsymbol{B}$, insets). $\boldsymbol{A}$, Intraplantar formalin ( $10 \mu \mathrm{l}$ of $5.4 \%$ formalin) produced a significant increase in pain-related behaviors in PPTA $^{+/+}$mice, whereas the maximal pain score was lowered in PPTA ${ }^{-1-}$ mice during the first few minutes after injection. ${ }^{* *} p<0.001$, two-way ANOVA with Bonferroni's post hoc test. $\boldsymbol{B}$, Subcutaneous capsaicin ( $6 \mu \mathrm{g}$ in $10 \mu \mathrm{l}$ ) produced a significant increase in pain-related behaviors in PPTA ${ }^{+/+}$mice, an effect that was reduced in PPTA ${ }^{-/-}$mice over the first 15 min of the test. ${ }^{* *} p<0.01$, two-way ANOVA with Bonferroni's post hoc test. The numbers in parentheses represent the number of animals per group. Error bars indicate SEM.

the test were analyzed, as confirmed by a significant decrease in the AUC (Fig. 2C; AUC, $2.3 \pm 0.8$ for Dlt II vs $20.9 \pm 2.2$ for saline; $p<0.0001, F=19.3$, one-way ANOVA followed by Bonferroni's multiple-comparison test). Administration of NTI (50 $\mathrm{nmol}$ ) before Dlt II reversed, at least partially, the analgesic effects of Dlt II (Fig. 2A, C; AUC, $13.6 \pm 1.9$ for NTI plus Dlt II vs $2.3 \pm$ 0.8 for Dlt II). Similarly, intrathecal DAMGO (1 $\mu$ g; Fig. $2 B, C)$ reduced formalin-evoked pain behaviors, an effect that was abolished by preinjection of CTOP ( $6 \mathrm{nmol})$, a MOPR-selective antagonist (Fig. 2 B, C; AUC, $8.3 \pm 2.8$ for DAMGO vs $18.5 \pm 1.7$ for CTOP plus DAMGO). These results demonstrate that both 


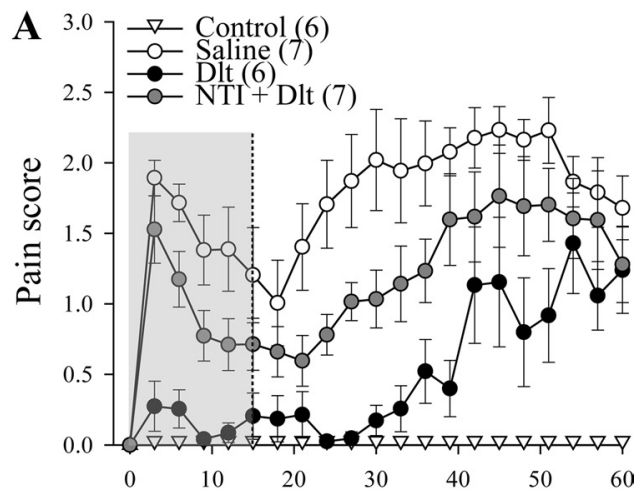

Time after formalin injection ( $\mathrm{min})$

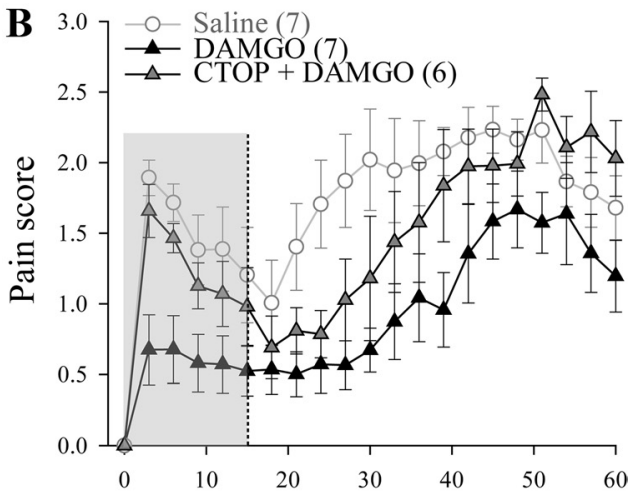

Time after formalin injection (min)

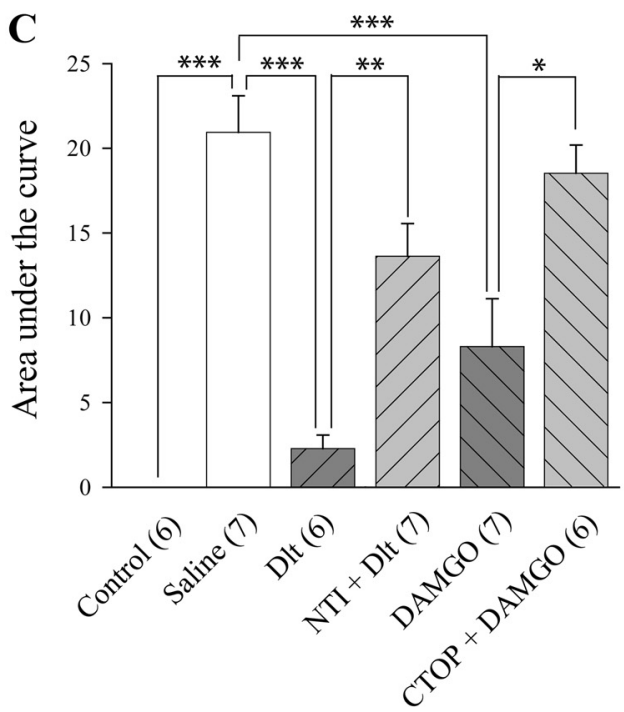

Figure 2. Inhibition of formalin-induced pain behavior following activation of DOPR and MOPR. Sprague Dawley male rats were injected with intradermal formalin $(50 \mu \mathrm{l}$ of $5.4 \%$ ) in the plantar surface of the hindpaw, and pain behaviors were recorded during 60 $\min . A$, Unlike intraplantar injection of saline, intraplantar injection of formalin produced a biphasic nociceptive response. Intrathecally administered deltorphin II (10 $\mu \mathrm{g} ; 12.7$ $\mathrm{nmol}$ ) produced a decrease in formalin-induced pain behaviors. NTI $(50 \mathrm{nmol})$ reversed the effects of Dlt II. $\boldsymbol{B}$, Intrathecally administered DAMGO $(1 \mu \mathrm{g} ; 1.9 \mathrm{nmol})$ produced a decrease in formalin-induced pain behaviors compared with saline (for reference purpose, results presented are the same as in $A)$. CTOP coinjection $(6 \mathrm{nmol})$ reversed the effects of DAMGO. C, Graphic representation of AUC for the first $15 \mathrm{~min}$ (highlighted by a gray area in $\boldsymbol{A}$ and $\boldsymbol{B}$ ) was calculated from data presented in $\boldsymbol{A}$ and $\boldsymbol{B} .{ }^{*} p<0.05,{ }^{* *} p<0.01$, and ${ }^{* * *} p<0.001$, one-way ANOVA with Bonferroni's post hoc test. The numbers in parentheses represent the number of animals per group. Error bars indicate SEM.
DOPR and MOPR agonists can reduce formalin-induced pain behaviors when injected intrathecally and that this effect is present during the first 15 min of the test (Fig. $2 A, B$, highlighted by a gray area), a period of time during which SP release is partially involved in the pain-like behaviors induced by intradermal formalin.

\section{Reduction of formalin-induced neuronal activation by DOPR and MOPR agonists}

Expression of c-fos is commonly used as a marker of neuronal activation (Hunt et al., 1987; Coggeshall, 2005) and a positive correlation between formalin-induced pain behaviors and c-fos expression was described previously (Gogas et al., 1996). Indeed, formalin is known to induce c-fos expression in spinal dorsal horn neurons (Williams et al., 1990), including $\mathrm{NK}_{1}$ projection neurons (Todd et al., 2002). As seen in Figure $3 A$, only a few c-fos-positive neurons were found in the spinal cord of control rats injected intradermally with saline. Conversely, intradermal formalin induced a robust, unilateral increase in the number of c-fos-positive neurons in superficial laminae I-II of the spinal cord after $1 \mathrm{~h}$ (Fig. $3 B ; 30 \pm 2$ neurons for saline vs $7 \pm 1$ neurons for control). Intrathecal Dlt II (10 $\mu \mathrm{g})$ decreased the number of c-fos-positive neurons in laminae I and II (Fig. 3C; $14 \pm 3$ neurons), and this effect was DOPR mediated because it was blocked by $50 \mathrm{nmol}$ of NTI (Fig. $3 D ; 39 \pm 3$ neurons). DAMGO also significantly reduced the number of c-fos-positive neurons in laminae I and II (Fig. 3E; $18 \pm 2$ neurons), an effect abolished by $6 \mathrm{nmol}$ of CTOP (Fig. 3F; $32 \pm 3$ neurons). Surprisingly, CTOP administration also caused a significant increase in c-fos expression in deeper laminae III-IV (Fig. 3G; $8 \pm 2$ neurons for saline vs $23 \pm 2$ neurons for CTOP plus DAMGO). This could possibly be explained by the inhibition of endogenous opioid tone by CTOP (Ossipov et al., 1996; Martin et al., 2003). The quantitative analysis of the number of c-fos-positive neurons in laminae I-II, III-IV, and V-VI is shown in Figure $3 G\left(p<0.0001\right.$ and $F_{\text {interaction }}=$ $6.628, F_{\text {treatment }}=27.70$ and $F_{\text {laminae }}=47.55$, two-way ANOVA followed by Bonferroni's multiple-comparison test). These results indicate that activation of DOPR and MOPR both inhibit formalin-induced pain behavior by blocking activation of spinal neurons.

\section{Inhibition of capsaicin-induced pain behaviors following activation of DOPR and MOPR}

Subcutaneous capsaicin binds to and activates TRPV1, which gives rise to pain-like behaviors such as licking, biting, and flinching (Sawynok et al., 2006). In this study, we evaluated capsaicininduced pain score in a similar manner as that used for the formalin test. As shown in Figure 4A, injection of capsaicin in the hindpaw induced rapid and sustained pain-like behaviors, while injection of vehicle had no effect. Capsaicin-induced pain behaviors were significantly reduced by intrathecal injection of Dlt II $(10 \mu \mathrm{g})$, at least when the AUC for the first $15 \mathrm{~min}$ following injection of capsaicin (Fig. $4 A, B$, highlighted by a gray area) was analyzed (Fig. $4 A, C$; AUC, $5.9 \pm 1.8$ for Dlt II vs $22.5 \pm 1.5$ for saline; $p<0.0001, F=26.77$, one-way ANOVA followed by Bonferroni's multiple-comparison test). This effect was mediated by DOPR, because it was completely reversed by NTI $(50 \mathrm{nmol}$; Fig. $4 A, C$; AUC, $22.3 \pm 1.8$ for NTI plus Dlt II vs $5.9 \pm 1.8$ for Dlt II). Similarly, DAMGO was also efficient at reducing capsaicininduced pain behaviors ( $1 \mu \mathrm{g}$; Fig. $4 B, C)$, an effect that was reduced by preinjection of CTOP (6 nmol; Fig. $4 B, C$; AUC, $11.1 \pm 2.8$ for DAMGO vs $19.9 \pm 1.3$ for CTOP plus DAMGO). 

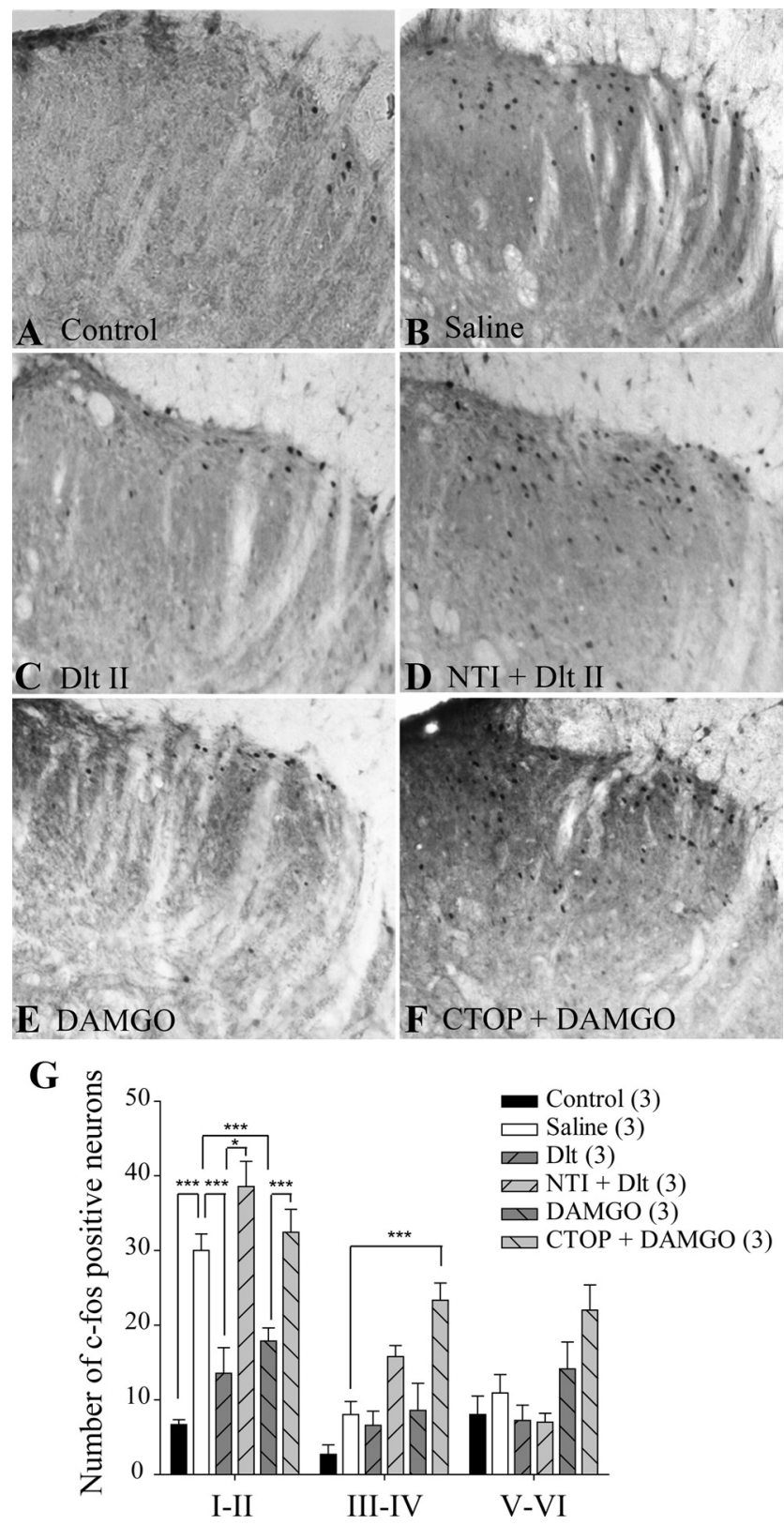

Figure 3. Reduction of formalin-induced neuronal activation by DOPR and MOPR agonists. Sprague Dawley male rats were injected with intradermal formalin (50 $\mu \mathrm{l}$ of $5.4 \%)$ in the plantar surface of the hindpaw, and c-fos expression in the spinal cord was observed by immunohistochemistry. When intradermal vehicle was injected, little c-fos expression was observed $(\boldsymbol{A})$, whereas formalin induced robust $\mathrm{C}-$ fos expression $(\boldsymbol{B})$. $\boldsymbol{C}$, Rats treated with intrathecal Dlt II $(10 \mu \mathrm{g} ; 12.7 \mathrm{nmol}) 5 \mathrm{~min}$ before formalin displayed a significant reduction in c-fos expression. $D$, NTI $(50 \mathrm{nmol})$ reversed the effects of Dlt II. $\boldsymbol{E}$, Intrathecal DAMGO $(1 \mu \mathrm{g} ; 1.9 \mathrm{nmol})$ also produced a reduction in c-fos expression, and this effect was suppressed by (TOP $(6 \mathrm{nmol})(\boldsymbol{F})$. CTOP also induced an increase in c-fos expression in deeper laminae $(\boldsymbol{F})$. G, Graphic representation of the number of c-fos-positive neurons. ${ }^{*} p<0.05$ and ${ }^{* * *} p<0.001$, two-way ANOVA with Bonferroni's post hoc test. The numbers in parentheses represent the number of animals per group. Error bars indicate SEM.

Together, these results show that DOPR and MOPR agonists can reduce capsaicin-induced pain behavior.

Reduction of capsaicin-induced neuronal activation by DOPR and MOPR agonists

Subcutaneous capsaicin is also a noxious stimulus that increases c-fos expression in dorsal horn spinal cord neurons (Kalezic et al.,

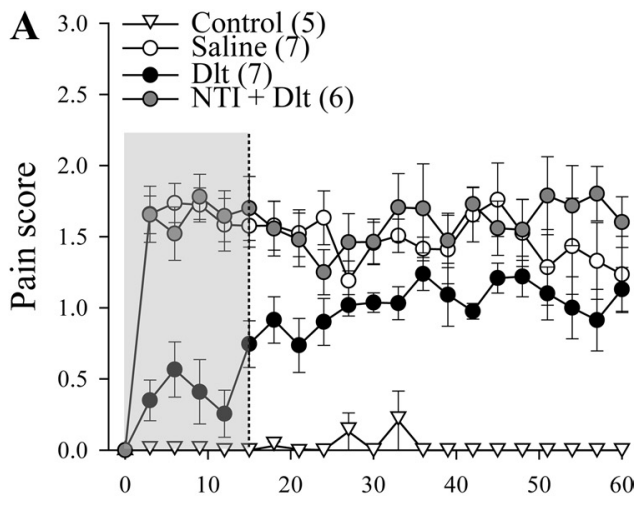

Time after capsaicin injection (min)

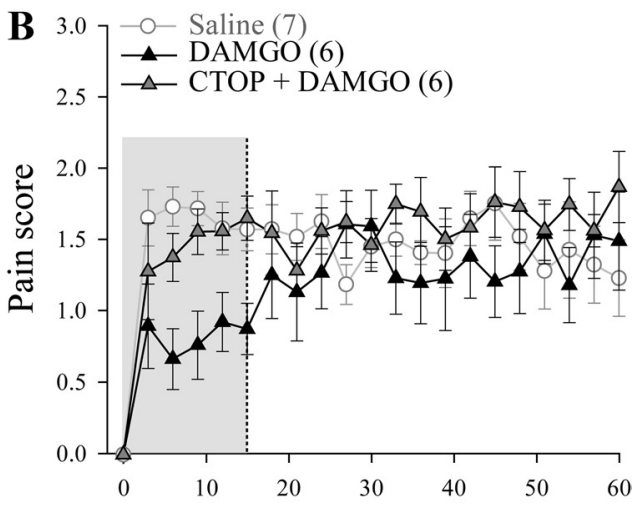

Time after capsaicin injection (min)

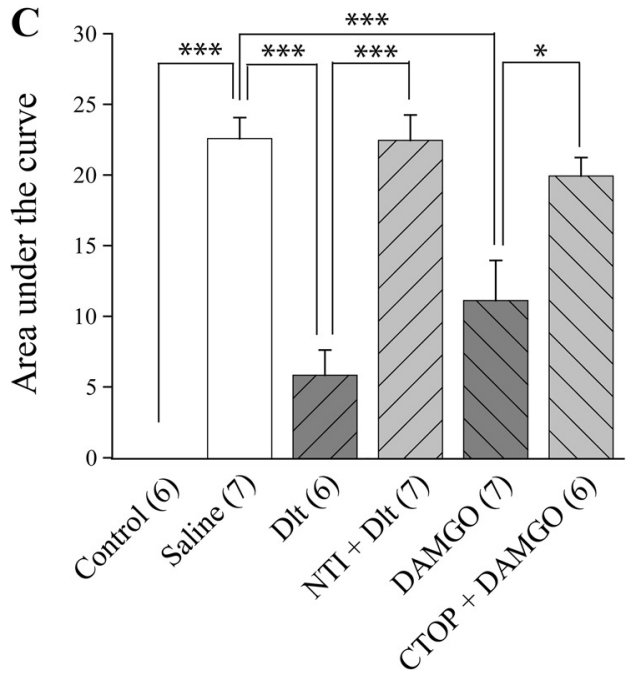

Figure 4. Inhibition of capsaicin-induced pain behaviors following activation of DOPR and MOPR. Sprague Dawley male rats were injected with subcutaneous capsaicin (15 $\mu \mathrm{g}$ in $50 \mu \mathrm{l}$ ) in the plantar surface of the hindpaw, and pain behaviors were recorded from 0 to $60 \mathrm{~min}$. The first $15 \mathrm{~min}$ were analyzed further. $A$, No pain behavior was noted in rats treated subcutaneously with vehicle. Conversely, subcutaneous injection of capsaicin produced pain behaviors that were decreased by intrathecally administered deltorphin II (10 $\mu \mathrm{g} ; 12.7 \mathrm{nmol})$. NTI preinjection $(50 \mathrm{nmol})$ reversed the effects of Dlt II. $\boldsymbol{B}$, Intrathecally administered DAMGO $(1 \mu \mathrm{g} ; 1.9 \mathrm{nmol})$ produced a decrease in capsaicin-induced pain behaviors. (TOP preinjection $(6 \mathrm{nmol})$ reversed the effects of DAMGO, compared with saline (results presented are the same as in $\boldsymbol{A}$ ). $\boldsymbol{C}$, Graphic representation of AUC obtained from the first $15 \mathrm{~min}$ of $\boldsymbol{A}$ and $\boldsymbol{B} .{ }^{*} p<0.05$ and ${ }^{* * *} p<0.001$ with Bonferroni's post hoc test. The numbers in parentheses represent the number of animals per group. Error bars indicate SEM. 

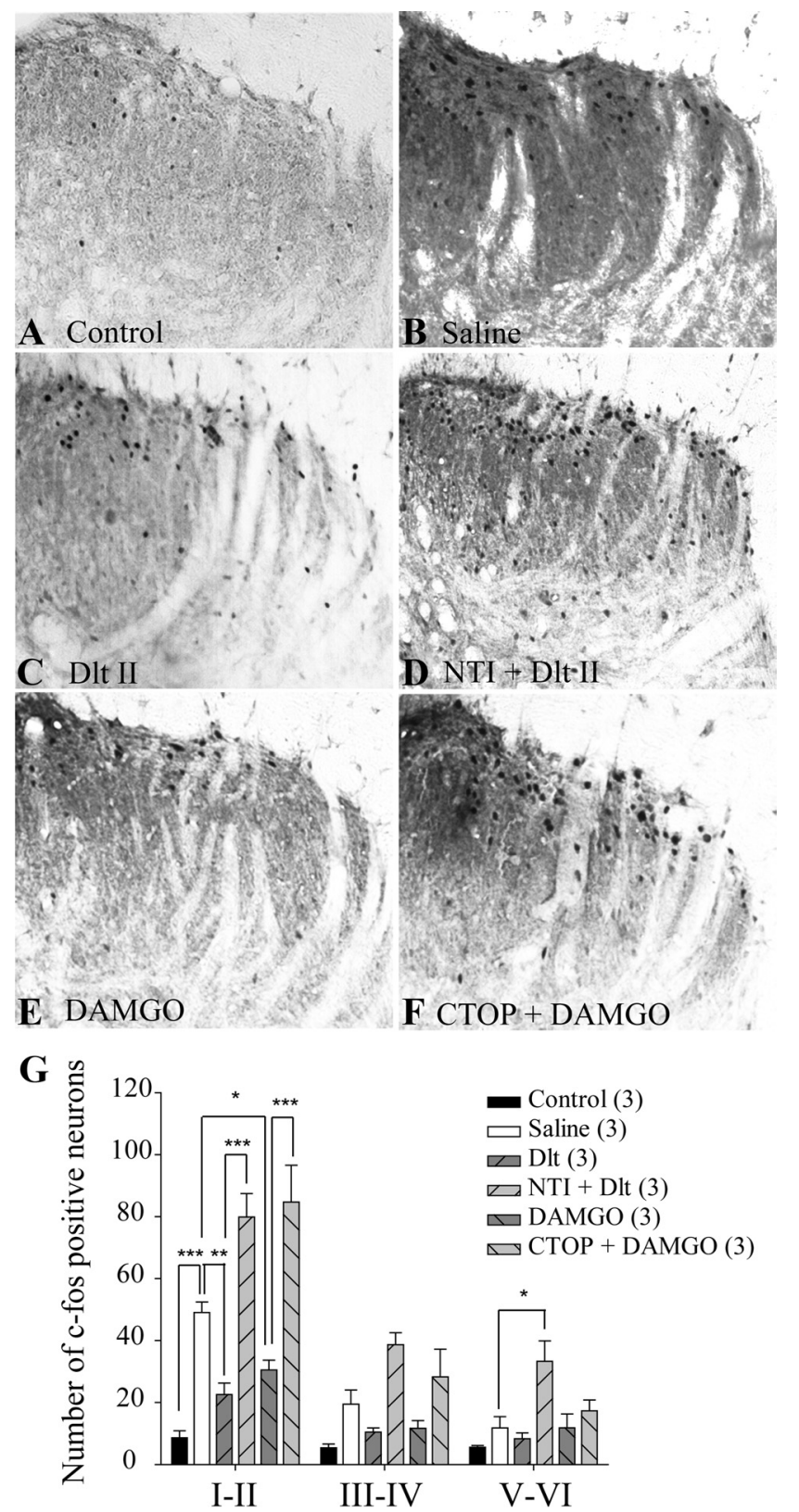

Figure 5. Reduction of capsaicin-induced neuronal activation by DOPR and MOPR agonists. Sprague Dawley male rats were injected with capsaicin (15 $\mu \mathrm{g}$ in $50 \mu \mathrm{l})$ in the plantar surface of the hindpaw, and c-fos expression in the spinal cord was observed by immunohistochemistry. When subcutaneous vehicle was injected in the paw, little c-fos expression was observed $(\boldsymbol{A})$, whereas capsaicin induced robust $\mathrm{C}-$ fos expression $(\boldsymbol{B})$. $\boldsymbol{C}$, When rats were treated intrathecally with Dlt II (10 $\mu \mathrm{g} ; 12.7 \mathrm{nmol}) 5 \mathrm{~min}$ before capsaicin injection, a significant reduction in c-fos expression was observed. D, NTI preinjection ( $50 \mathrm{nmol}, 5 \mathrm{~min}$ before Dlt II) reversed the effects of Dlt Il but also increased c-fos expression in deeper laminae. $\boldsymbol{E}$, Intrathecal DAMGO (1 $\mu \mathrm{g} ; 1.9$ $\mathrm{nmol}$ ) also produced a reduction in c-fos expression, and its effect was suppressed by a preinjection of (TOP $(6 \mathrm{nmol})(\boldsymbol{F})$. $\boldsymbol{G}$, Graphic representation of the number of c-fospositive neurons. ${ }^{*} p<0.05,{ }^{* *} p<0.01$, and ${ }^{* * *} p<0.001$, two-way ANOVA with Bonferroni's post hoc test. The numbers in parentheses represent the number of animals per group. Error bars indicate SEM.

2004). In the present study, we confirmed that subcutaneous capsaicin induced a unilateral increase in the number of c-fospositive laminae I-II neurons in the lumbar spinal cord when compared with vehicle-treated rats (Fig. 5, compare $B, A$; but see also $G ; 49 \pm 3$ neurons for saline vs $9 \pm 2$ neurons for control). Intrathecal Dlt II was found to reduce capsaicin-induced neuro- nal activation (Fig. 5C,G; $23 \pm 4$ neurons). When rats were pretreated with NTI, the effect of Dlt II was completely abolished. We further observed that NTI pretreatment $(50 \mathrm{nmol})$ by itself caused an increase in c-fos expression in deeper laminae V-VI (Fig. 5D, G; $80 \pm 8$ neurons for laminae I-II and $33 \pm 7$ neurons for laminae V-VI). DAMGO was also found to produce a robust decrease in the number of c-fos-expressing neurons (Fig. $5 E, G$; $31 \pm 3$ neurons), an effect abolished by CTOP ( 6 nmol; Fig. 5 F, G; $85 \pm 12$ neurons). The quantitative analysis of the number of c-fos-positive neurons in laminae I-II, III-IV, and V-VI is shown in Figure $5 G\left(p<0.0001\right.$ and $F_{\text {interaction }}=5.502, F_{\text {treatment }}=$ 34.81 and $F_{\text {laminae }}=63.82$, two-way ANOVA followed by Bonferroni's multiple-comparison test). These results indicate that DOPR and MOPR can inhibit capsaicin-induced pain behaviors by blocking the activation of spinal neurons.

\section{Formalin- and capsaicin-induced $\mathrm{NK}_{1} \mathrm{R}$ internalization}

Following activation of primary afferent fibers by formalin and capsaicin, SP is released in the superficial laminae of the spinal cord, where it binds to and activates $\mathrm{NK}_{1} \mathrm{R}$. Upon activation, $\mathrm{NK}_{1}$ Rs are rapidly internalized (Mantyh et al., 1995; Abbadie et al., 1997; Marvizón et al., 2003; Nazarian et al., 2008). $\mathrm{NK}_{1} \mathrm{R}$ internalization can therefore be used as an indication of SP release. As shown in Figure $6 A$, immunostaining of $\mathrm{NK}_{1} \mathrm{R}$ in the rat spinal cord revealed intense immunofluorescent labeling in superficial laminae I-II. In control rats, the $\mathrm{NK}_{1} \mathrm{R}$-like immunoreactivity is mainly located at the cell surface. In animals pretreated with intrathecal saline and intradermal formalin in the left hindpaw, the $\mathrm{NK}_{1} \mathrm{R}$ immunostaining in the ipsilateral side appeared to be punctate and was localized at the intracellular level in vesicle-like structures in the vast majority of neurons (Fig. 6C,N; $77.2 \pm 8.3 \%$ of laminae I-II neurons have internalized $\mathrm{NK}_{1} \mathrm{R}$ ), suggesting that formalin induced SP-mediated internalization of $\mathrm{NK}_{1} \mathrm{R}$. By contrast, only discrete $\mathrm{NK}_{1} \mathrm{R}$ internalization was observed contralaterally from the formalin injection (Fig. $6 B, N$; $13.0 \pm 5.7 \%)$. Intrathecal Dlt II ( $30 \mu$ g; Fig. $6 D, N ; 34.1 \pm 2.2 \%)$ as well as DAMGO (10 $\mu$ g; Fig. $6 F, N ; 25.9 \pm 3.1 \%)$ significantly decreased the proportion of neurons with internalized $\mathrm{NK}_{1} \mathrm{R}$ (Fig. $6 N ; p<0.0001, F=32.45$, one-way ANOVA followed by Bonferroni's multiple-comparison test). Note that the effects of Dlt II and DAMGO were blocked by NTI (150 nmol) and CTOP $(30 \mathrm{nmol}$ ), respectively (Fig. $6 E, G, N)$. Similar results were obtained following intraplantar capsaicin injection. Indeed, capsaicin-induced $\mathrm{NK}_{1} \mathrm{R}$ internalization was observed unilaterally (Fig. 6, compare $I, H ; 74.1 \pm 9.3 \%$ of ipsilateral laminae I-II neurons have internalized $\mathrm{NK}_{1} \mathrm{R}$, compared with only $8.7 \pm 5.2 \%$ in the contralateral side). In animals pretreated with $30 \mu \mathrm{g}$ of Dlt II intrathecally, a significant decrease in the proportion of neurons showing $\mathrm{NK}_{1} \mathrm{R}$ internalization was observed (Fig. 6J,N; $31.9 \pm 6.9 \%$ of ipsilateral laminae I-II neurons with internalized $\mathrm{NK}_{1} \mathrm{R}$ ), an effect also observed following intrathecal injection of $10 \mu \mathrm{g}$ of DAMGO (Fig. $6 L, N ; 29.2 \pm 3.7 \% ; p=0.0009, F=$ 11.71, one-way ANOVA followed by Bonferroni's multiplecomparison test). These effects were blocked by the selective DOPR and MOPR antagonists NTI and CTOP (Fig. $6 K, M, N$ ). These results suggest that DOPR and MOPR are both able to inhibit SP release from primary afferents.

\section{SP-induced $\mathrm{NK}_{\mathbf{1}} \mathrm{R}$ internalization}

To confirm that inhibition of $\mathrm{NK}_{1}$ receptor internalization was due to an inhibition of SP release and not due to a direct action of MOPR and DOPR agonists on $\mathrm{NK}_{1} \mathrm{R}$-expressing neurons, $\mathrm{SP}$ was injected intrathecally in rats pretreated with Dlt II or DAMGO. 
We observed that intrathecal SP injection produced a robust bilateral $\mathrm{NK}_{1} \mathrm{R}$ internalization, compared with control rats (Fig. 7, compare $B, A$ ). Pretreatment with $30 \mu \mathrm{g}$ of Dlt II intrathecally (Fig. $7 C$ ) or 10 $\mu \mathrm{g}$ of DAMGO intrathecally (Fig. 7D) failed to prevent intrathecal SP-induced $\mathrm{NK}_{1} \mathrm{R}$ internalization. These results indicate that DOPR and MOPR agonists do not interfere with the mechanisms of $\mathrm{NK}_{1} \mathrm{R}$ internalization and further support the observation that intrathecal opioid-mediated blockade of formalinand capsaicin-induced $\mathrm{NK}_{1} \mathrm{R}$ internalization occurs via the inhibition of SP release from primary afferents.

\section{Discussion}

In the present study, we investigated the role of DOPR and MOPR on pain behavior, neuronal activation, and SP release induced by intraplantar formalin and capsaicin. We demonstrated that intrathecally administered DOPR and MOPR agonists were able to decrease formalin- and capsaicin-induced pain behaviors as well as to block activation of spinal cord neurons. By visualizing $\mathrm{NK}_{1} \mathrm{R}$ internalization, we also showed that DOPR- and MOPR-selective agonists inhibit formalin- and capsaicininduced SP release via direct action on primary afferents. Together, our results reveal that DOPR and MOPR are both expressed by SP-containing neurons and that activation of these receptors alleviates pain, at least in part, by reducing SP release from primary afferents.

Our group has shown that DOPRmediated analgesia was increased by morphine pretreatment (Cahill et al., 2001; Morinville et al., 2004b; Gendron et al., 2007a) and by chronic inflammatory pain (Cahill et al., 2003; Gendron et al., 2007a; Beaudry et al., 2009). Interestingly, the enhanced analgesic effects of DOPR agonists under these conditions was shown to be accompanied by an increase in the expression of DOPRs on the cell surface of spinal cord and DRG neurons (Cahill et al., 2001, 2003; Morinville et al., 2003, 2004b; Gendron et al., 2006). Although the exact mechanisms have not been identified, we previously observed that MOPR was involved in regulating these processes (Morinville et al., 2003, 2004a; Gendron et al., 2007b). At a molecular level, coexpression of MOPR and DOPR within the same structures might be required for MOPR to regulate DOPR trafficking and function. Indeed, although MOPR and DOPR were shown to physically interact and dimerize in vitro (George et al., 2000; Gomes et al., 2000, 2004; Hasbi et al., 2007; Décaillot et al., 2008; Gupta et al., 2010; Kabli et al., 2010), the in vivo coexpression of these receptors in the same cells is still a matter of contro-

$\mathbf{N}$ indicate SEM.
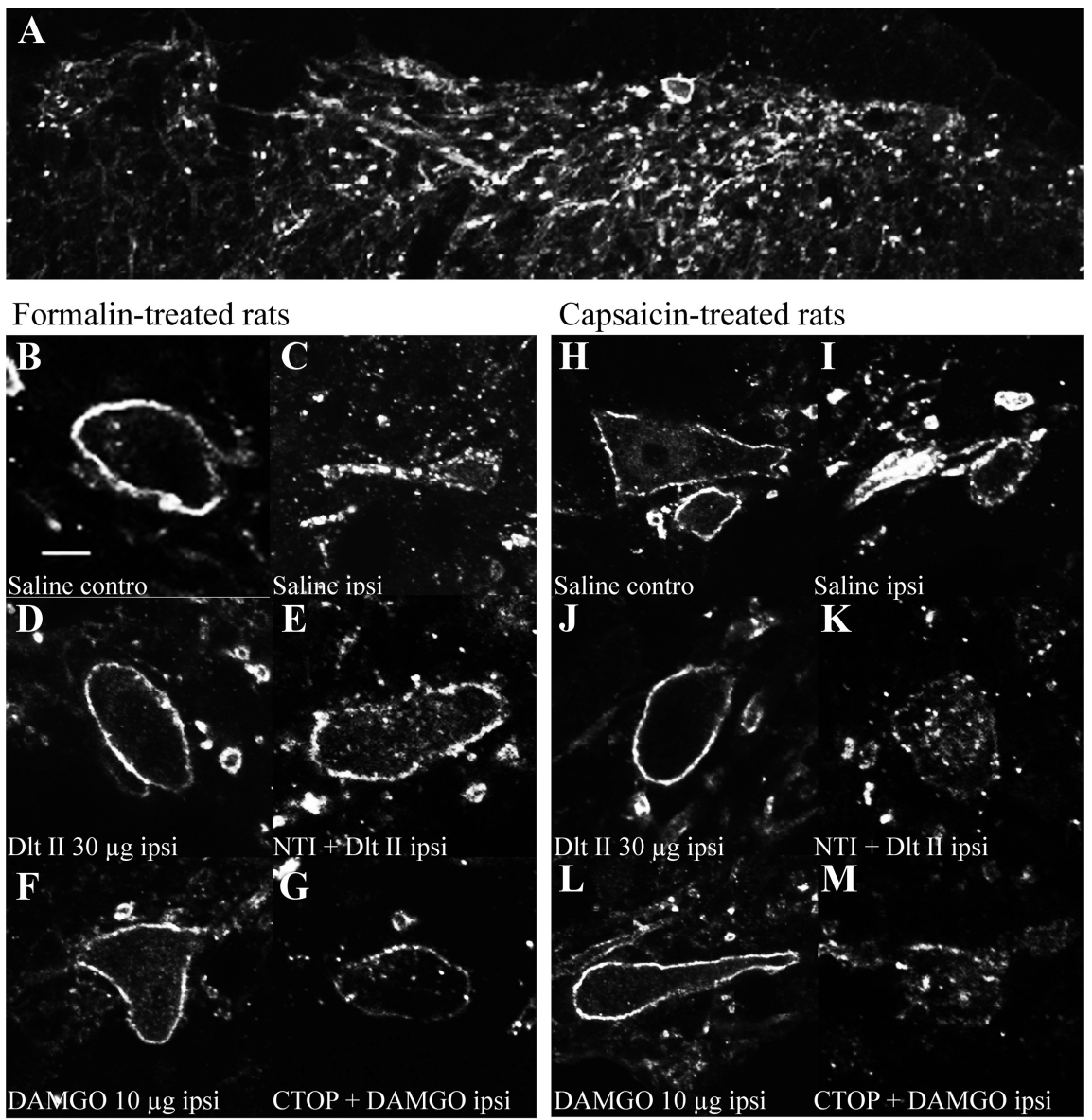

Capsaicin-treated rats
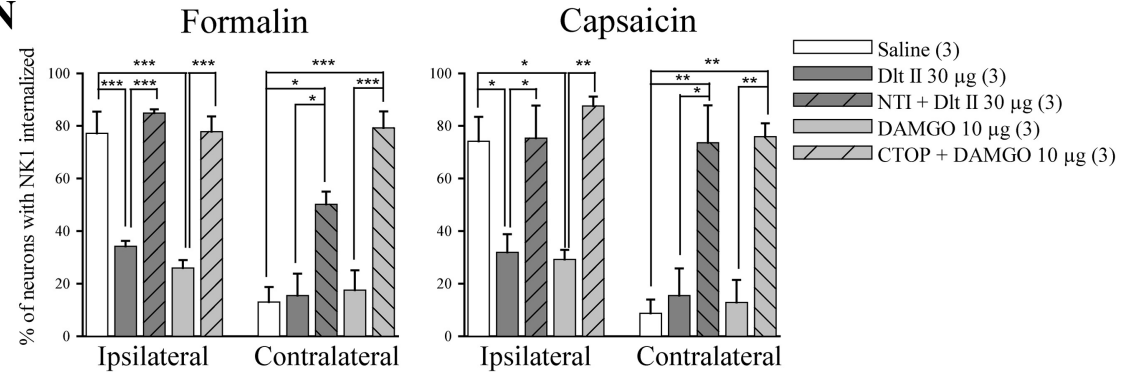

Figure 6. Formalin- and capsaicin-induced $\mathrm{NK}_{1} \mathrm{R}$ internalization. $\mathrm{NK}_{1} \mathrm{R}$ internalization in the spinal cord of male Sprague Dawley rats was observed by immunofluorescence. $A$, In control rats, NK $\mathrm{N}_{1}$-like immunostaining was clearly visible throughout the superficial laminae of the spinal cord. Immunolabeling of $\mathrm{NK}_{1} \mathrm{R}$ appeared at the cell surface. Ten minutes following intradermal injection of formalin, $\mathrm{NK}_{1} \mathrm{R}$ immunostaining in the ipsilateral side appeared as being inside the cells in vesicle-like structures (C). By contrast, $\mathrm{NK}_{1} \mathrm{R}$ labeling in the contralateral side of the spinal cord remained at the cell surface $(\boldsymbol{B})$. When Dlt II ( $\left.30 \mu \mathrm{g} ; 38.1 \mathrm{nmol}\right)$ was injected intrathecally 5 min before formalin, a significant reduction in $\mathrm{NK}_{1} \mathrm{R}$ internalization was observed (D). This effect was blocked by NTI ( $150 \mathrm{nmol})$ (E). A similar effect was seen when DAMGO $(10 \mu \mathrm{g} ; 19.4 \mathrm{nmol})$ was injected intrathecally 5 min before formalin $(\boldsymbol{F})$, an effect blocked by (TOP ( $30 \mathrm{nmol})(\boldsymbol{G})$. Similarly, capsaicin induced a robust $\mathrm{NK}_{1}$ R internalization in the ipsilateral side of the spinal cord $(\boldsymbol{I})$ but not on the contralateral side $(\boldsymbol{H})$. Injection of Dlt II $(\boldsymbol{J})$ or DAMGO $(\boldsymbol{L}) 5 \mathrm{~min}$ before capsaicin injection prevented $\mathrm{NK}_{1}$ R internalization. Again, the effects of DIt and DAMGO were blocked by preinjection of NTI and CTOP, respectively $(\boldsymbol{K}$, $\boldsymbol{M}) . \boldsymbol{N}$, Graphic representation of the percentage of neurons with internalized $\mathrm{NK}_{1}$ R induced by formalin and capsaicin injections for ipsilateral and contralateral sides of the lumbar spinal cord. ${ }^{*} p<0.05,{ }^{* *} p<0.01$, and ${ }^{* * *} p<0.001$, one-way ANOVA with Bonferroni's post hoc test. The numbers in parentheses represent the number of animals per group. Scale bar: $\boldsymbol{B}, 30 \mu \mathrm{m}$. Error bars

versy. In mouse DRGs, MOPRs were shown to be expressed by SP-containing neurons, whereas DOPRs were mainly found in nonpeptidergic neurons (Mennicken et al., 2003; Scherrer et al., 2009). These observations are in sharp contrast with findings from others suggesting that (1) DOPR physically interacts with the precursor of SP in DRGs (Guan et al., 2005); (2) DOPR is expressed in SP- (Guan et al., 2005; Riedl et al., 2009; Wang et al., 

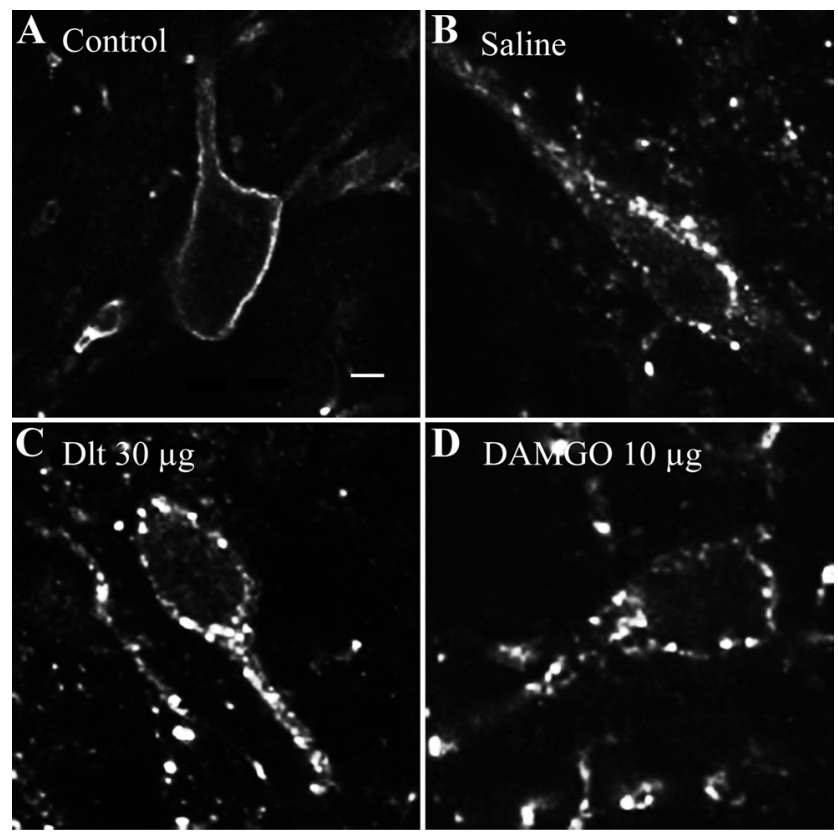

Figure 7. SP-induced $\mathrm{NK}_{1} \mathrm{R}$ internalization. The effects of Dlt II or DAMGO on exogenous SPinduced $\mathrm{NK}_{1}$ R internalization were verified by immunofluorescence. In control rats, no NK 1 R internalization was observed in a majority of neurons $(\boldsymbol{A})$, whereas intrathecal injection of SP (22 nmol) induced robust $\mathrm{NK}_{1} \mathrm{R}$ localization in intracellular, vesicle-like structures $(\boldsymbol{B})$. Neither intrathecal Dlt II (30 $\mu \mathrm{g} ; 38.1 \mathrm{nmol})$ nor DAMGO (10 $\mu \mathrm{g} ; 19.4 \mathrm{nmol})$ treatment $5 \mathrm{~min}$ before SP injection was able to block the $S P$-induced $\mathrm{NK}_{1}$ R internalization $(\boldsymbol{C}, \boldsymbol{D}$, respectively). Scale bar: $\boldsymbol{A}, 20 \mu \mathrm{m}$.

2010; Zhao et al., 2011) and CGRP (calcitonin gene-related peptide)-containing terminals (Overland et al., 2009); (3) DOPR and MOPR mRNAs are often coexpressed in SP-containing neurons (Minami et al., 1995; Wang et al., 2010); and (4) the amount of MOPR-DOPR hetero-oligomers in DRG neurons is increased by morphine treatment (Gupta et al., 2010).

Using formalin and capsaicin as noxious stimuli, the present study aimed to investigate the functional role of MOPR and DOPR and to determine whether these receptors are expressed in SP-containing primary afferent nociceptors. Formalin and capsaicin, activating TRPA1 (McNamara et al., 2007) and TRPV1 (Caterina et al., 1997) ion channels, respectively, are known to induce SP release by primary afferents (Mantyh et al., 1995; Tao and Zhao, 1997; Tao et al., 1997; Honor et al., 1999; Todd et al., 2002; Lao et al., 2003; Greco et al., 2008). Using mice in which the precursor for SP was inactivated, we demonstrated that the absence of SP slightly but significantly decreased early pain behaviors induced by injection of formalin and capsaicin into the hindpaw, an effect that has also been noted by others (Cao et al., 1998; Zimmer et al., 1998).

The analgesic efficacy of intrathecally delivered DOPR (Ossipov et al., 1996; Hammond et al., 1998; Cahill et al., 2001; Labuz et al., 2003) and MOPR (Murray and Cowan, 1991; Hammond et al., 1998; Nishiyama, 2000) agonists in the formalin test has been described. The MOPR-selective agonist DAMGO was also shown to reduce capsaicin-induced scratching, biting, and licking behaviors (Watanabe et al., 2006). The ability of spinally administered DAMGO to inhibit formalin- and capsaicin-induced pain behaviors was confirmed in this study. A provocative study by Scherrer et al. (2009) recently suggested that spinal activation of MOPR in mice specifically inhibits thermal hyperalgesia. By contrast, these authors showed that intrathecal administration of a selective DOPR agonist was only efficient at alleviating mechan- ical pain (Scherrer et al., 2009). Our results do not support the latter conclusion. Indeed, we demonstrated that intrathecal deltorphin II efficiently blocked formalin- and capsaicin-induced pain behaviors, therefore suggesting that activation of spinal DOPR potently inhibits TRPA1- and TRPV1-expressing, temperature-sensitive nociceptors. Admittedly, this could be explained by a species difference. One could also argue that the effect of deltorphin II could be mediated by a direct action on MOPR, as described previously (Scherrer et al., 2004). However, using DOPR- and MOPR-selective antagonists, we clearly established that the effects of deltorphin II and DAMGO were DOPR and MOPR mediated, respectively. Therefore, our results further support our previous publications describing the role of DOPRs in alleviating complete Freund's adjuvant-induced thermal hyperalgesia in rodents (Gendron et al., 2007a,b; Beaudry et al., 2009; Dubois and Gendron, 2010).

As shown by others and extensively reviewed by Coggeshall (2005), we observed that intradermal formalin and intraplantar capsaicin induced a robust increase of c-fos expression in spinal dorsal horn neurons. Formalin-induced c-fos expression occurs both in $\mathrm{NK}_{1} \mathrm{R}$-positive neurons (Doyle and Hunt, 1999; Todd et al., 2002) and in neurons located in the close vicinity of SPcontaining terminals (Tao and Zhao, 1997; Tao et al., 1997). MOPR- and DOPR-mediated inhibition of c-fos expression in dorsal horn neurons confirmed that intrathecal DAMGO and deltorphin II both potently blocked the activation of neurons in superficial "pain-processing" laminae. These observations are in accordance with others who have shown that DOPR and MOPR agonists can efficiently decrease formalin-induced c-fos expression associated with pain behaviors (Hammond et al., 1998; Labuz et al., 2003). In this study, we demonstrated for the first time that c-fos expression induced by intraplantar capsaicin can be inhibited by selective spinal DOPR and MOPR activation. However, it is not possible to discriminate between presynaptic and postsynaptic effects of opioids based solely on the inhibition of pain-like behaviors and c-fos expression in spinal dorsal horn neurons nor is it possible to conclude that MOPR and DOPR agonists are targeting the same subset of neurons.

In an attempt to see whether MOPR and DOPR could regulate a common subset of neurons, we focused on evaluating the effects of MOPR- and DOPR-selective agonists on SP release. Early studies have shown that peripheral noxious stimuli induce the internalization of $\mathrm{NK}_{1} \mathrm{R}$ in lamina I neurons (Mantyh et al., 1995; Abbadie et al., 1997). Using $\mathrm{NK}_{1} \mathrm{R}$ internalization as a tool to evaluate SP release, we demonstrated that selective activation of either MOPRs or DOPRs was sufficient to abolish formalin- and capsaicin-induced SP release. Interestingly, it was observed by others that MOPR agonists can decrease $\mathrm{NK}_{1} \mathrm{R}$ internalization induced by paw compression (Kondo et al., 2005) or intraplantar formalin (Nazarian et al., 2008). Similarly, Kondo et al. (2005) have also observed DOPR-mediated inhibition of mechanical stimulus-induced $\mathrm{NK}_{1} \mathrm{R}$ internalization. Admittedly, it could be claimed that MOPR and DOPR agonists may interfere with the $\mathrm{NK}_{1} \mathrm{R}$ internalization via direct action on spinal dorsal horn neurons that express $\mathrm{NK}_{1} \mathrm{R}$. In fact, both MOPR and DOPR agonists efficiently inhibit pain evoked by an intrathecal injection of SP in mice (Fairbanks et al., 2000), revealing a direct action of opioids on second-order spinal cord neurons. In rats, however, MOPR is rarely expressed in lamina I projection neurons (Spike et al., 2002; Song and Marvizón, 2003) but is actually present in spinal cord SP-containing axon terminals (Aicher et al., 2000). In the present study, we confirmed that intrathecal injection of SP induces robust $\mathrm{NK}_{1} \mathrm{R}$ internalization in lamina I neurons. Because 
this effect was not prevented by high doses of intrathecal deltorphin II or DAMGO, our results strongly suggest that both MOPR and DOPR agonists inhibit formalin- and capsaicin-induced $\mathrm{NK}_{1} \mathrm{R}$ internalization by decreasing SP release from primary afferents rather than via action on second-order neurons.

The major finding of this study is that MOPR and DOPR are both expressed by peptidergic nociceptors, where they potently inhibit formalin- and capsaicin-induced SP release in rat spinal cord. Despite the fact that opioid inhibition of second-order neurons might play a significant role in rodents, in humans, DOPR was shown to be predominantly expressed on small- to mediumsized primary afferents and not by spinal cord neurons (Mennicken et al., 2003). Therefore, our results are of particular importance to better understand the molecular and cellular mechanisms involved in the regulation of DOPR and to unravel its role in pain processing. Relying on functional evidence (behavior and $\mathrm{NK}_{1} \mathrm{R}$ internalization) and behavioral pharmacology rather than solely on immunolabeling of endogenous DOPR or on mice expressing chimeric receptors (i.e., tagged receptors), the present study clearly demonstrates that MOPR and DOPR agonists can act on a same subset of DRG neurons in vivo, namely SP-containing neurons, and can modulate similar pain modalities.

\section{References}

Abbadie C, Trafton J, Liu H, Mantyh PW, Basbaum AI (1997) Inflammation increases the distribution of dorsal horn neurons that internalize the neurokinin-1 receptor in response to noxious and non-noxious stimulation. J Neurosci 17:8049-8060.

Aicher SA, Sharma S, Cheng PY, Liu-Chen LY, Pickel VM (2000) Dual ultrastructural localization of mu-opiate receptors and substance $\mathrm{P}$ in the dorsal horn. Synapse 36:12-20.

Beaudry H, Proteau-Gagné A, Li S, Dory Y, Chavkin C, Gendron L (2009) Differential noxious and motor tolerance of chronic delta opioid receptor agonists in rodents. Neuroscience 161:381-391.

Bucsics A, Lembeck F (1981) In vitro release of substance P from spinal cord slices by capsaicin congeners. Eur J Pharmacol 71:71-77.

Cahill CM, Morinville A, Lee MC, Vincent JP, Collier B, Beaudet A (2001) Prolonged morphine treatment targets $\delta$-opioid receptors to neuronal plasma membranes and enhances $\delta$-mediated antinociception. J Neurosci 21:7598-7607.

Cahill CM, Morinville A, Hoffert C, O’Donnell D, Beaudet A (2003) Upregulation and trafficking of delta opioid receptor in a model of chronic inflammation: implications for pain control. Pain 101:199-208.

Cahill CM, Holdridge SV, Morinville A (2007) Trafficking of delta-opioid receptors and other G-protein-coupled receptors: implications for pain and analgesia. Trends Pharmacol Sci 28:23-31.

Cao YQ, Mantyh PW, Carlson EJ, Gillespie AM, Epstein CJ, Basbaum AI (1998) Primary afferent tachykinins are required to experience moderate to intense pain. Nature 392:390-394.

Caterina MJ, Schumacher MA, Tominaga M, Rosen TA, Levine JD, Julius D (1997) The capsaicin receptor: a heat-activated ion channel in the pain pathway. Nature 389:816-824.

Coderre TJ, Fundytus ME, McKenna JE, Dalal S, Melzack R (1993) The formalin test: a validation of the weighted-scores method of behavioural pain rating. Pain 54:43-50.

Coggeshall RE (2005) Fos, nociception and the dorsal horn. Prog Neurobiol 77:299-352.

Cornett PM, Matta JA, Ahern GP (2008) General anesthetics sensitize the capsaicin receptor transient receptor potential V1. Mol Pharmacol 74:1261-1268.

Décaillot FM, Rozenfeld R, Gupta A, Devi LA (2008) Cell surface targeting of mu-delta opioid receptor heterodimers by RTP4. Proc Natl Acad Sci U S A 105:16045-16050.

Doyle CA, Hunt SP (1999) Substance P receptor (neurokinin-1)-expressing neurons in lamina I of the spinal cord encode for the intensity of noxious stimulation: a c-Fos study in rat. Neuroscience 89:17-28.

Dubois D, Gendron L (2010) Delta opioid receptor-mediated analgesia is not altered in preprotachykinin A knockout mice. Eur J Neurosci 32:1921-1929.

Dubuisson D, Dennis SG (1977) The formalin test: a quantitative study of the analgesic effects of morphine, meperidine, and brain stem stimulation in rats and cats. Pain 4:161-174.

Fairbanks CA (2003) Spinal delivery of analgesics in experimental models of pain and analgesia. Adv Drug Deliv Rev 55:1007-1041.

Fairbanks CA, Posthumus IJ, Kitto KF, Stone LS, Wilcox GL (2000) Moxonidine, a selective imidazoline/alpha(2) adrenergic receptor agonist, synergizes with morphine and deltorphin II to inhibit substance P-induced behavior in mice. Pain 84:13-20.

Gendron L, Lucido AL, Mennicken F, O’Donnell D, Vincent JP, Stroh T, Beaudet A (2006) Morphine and pain-related stimuli enhance cell surface availability of somatic $\delta$-opioid receptors in rat dorsal root ganglia. J Neurosci 26:953-962.

Gendron L, Esdaile MJ, Mennicken F, Pan H, O’Donnell D, Vincent JP, Devi LA, Cahill CM, Stroh T, Beaudet A (2007a) Morphine priming in rats with chronic inflammation reveals a dichotomy between antihyperalgesic and antinociceptive properties of deltorphin. Neuroscience 144:263-274.

Gendron L, Pintar JE, Chavkin C (2007b) Essential role of $\mu$ opioid receptor in the regulation of $\delta$ opioid receptor-mediated antihyperalgesia. Neuroscience 150:807-817.

George SR, Fan T, Xie Z, Tse R, Tam V, Varghese G, O’Dowd BF (2000) Oligomerization of mu- and delta-opioid receptors. Generation of novel functional properties. J Biol Chem 275:26128-26135.

Gogas KR, Cho HJ, Botchkina GI, Levine JD, Basbaum AI (1996) Inhibition of noxious stimulus-evoked pain behaviors and neuronal fos-like immunoreactivity in the spinal cord of the rat by supraspinal morphine. Pain 65:9-15.

Gomes I, Jordan BA, Gupta A, Trapaidze N, Nagy V, Devi LA (2000) Heterodimerization of $\mu$ - and $\delta$-opioid receptors: a role in opiate synergy. J Neurosci 20:RC110(1-5).

Gomes I, Gupta A, Filipovska J, Szeto HH, Pintar JE, Devi LA (2004) A role for heterodimerization of $\mathrm{mu}$ and delta opiate receptors in enhancing morphine analgesia. Proc Natl Acad Sci U S A 101:5135-5139.

Greco R, Tassorelli C, Sandrini G, Di Bella P, Buscone S, Nappi G (2008) Role of calcitonin gene-related peptide and substance $\mathrm{P}$ in different models of pain. Cephalalgia 28:114-126.

Guan JS, Xu ZZ, Gao H, He SQ, Ma GQ, Sun T, Wang LH, Zhang ZN, Lena I, Kitchen I, Elde R, Zimmer A, He C, Pei G, Bao L, Zhang X (2005) Interaction with vesicle luminal protachykinin regulates surface expression of delta-opioid receptors and opioid analgesia. Cell 122:619-631.

Gupta A, Mulder J, Gomes I, Rozenfeld R, Bushlin I, Ong E, Lim M, Maillet E, Junek M, Cahill CM, Harkany T, Devi LA (2010) Increased abundance of opioid receptor heteromers after chronic morphine administration. Sci Signal 3:ra54.

Hack SP, Bagley EE, Chieng BC, Christie MJ (2005) Induction of $\delta$-opioid receptor function in the midbrain after chronic morphine treatment. J Neurosci 25:3192-3198.

Hammond DL, Wang H, Nakashima N, Basbaum AI (1998) Differential effects of intrathecally administered delta and mu opioid receptor agonists on formalin-evoked nociception and on the expression of Fos-like immunoreactivity in the spinal cord of the rat. J Pharmacol Exp Ther 284:378-387.

Hasbi A, Nguyen T, Fan T, Cheng R, Rashid A, Alijaniaram M, Rasenick MM, O'Dowd BF, George SR (2007) Trafficking of preassembled opioid mudelta heterooligomer-Gz signaling complexes to the plasma membrane: coregulation by agonists. Biochemistry 46:12997-13009.

Honor P, Menning PM, Rogers SD, Nichols ML, Basbaum AI, Besson JM, Mantyh PW (1999) Spinal substance P receptor expression and internalization in acute, short-term, and long-term inflammatory pain states. J Neurosci 19:7670-7678.

Hunt SP, Pini A, Evan G (1987) Induction of c-fos-like protein in spinal cord neurons following sensory stimulation. Nature 328:632-634.

Kabli N, Martin N, Fan T, Nguyen T, Hasbi A, Balboni G, O’Dowd BF, George SR (2010) Agonists at the delta-opioid receptor modify the binding of micro-receptor agonists to the micro-delta receptor hetero-oligomer. $\mathrm{Br} J$ Pharmacol 161:1122-1136.

Kalezic I, Pilyavskii AI, Maisky VA, Kostyukov AI, Windhorst U, Johansson H (2004) Distinctive pattern of c-fos expression in the feline cervicolumbar spinal cord after stimulation of vanilloid receptors in dorsal neck muscles. Neurosci Lett 364:94-97. 
Kantner RM, Goldstein BD, Kirby ML (1986) Regulatory mechanisms for substance $\mathrm{P}$ in the dorsal horn during a nociceptive stimulus: axoplasmic transport vs electrical activity. Brain Res 385:282-290.

Kondo I, Marvizon JC, Song B, Salgado F, Codeluppi S, Hua XY, Yaksh TL (2005) Inhibition by spinal $\mu$ - and $\delta$-opioid agonists of afferent-evoked substance P release. J Neurosci 25:3651-3660.

Labuz D, Chocyk A, Wedzony K, Toth G, Przewlocka B (2003) Endomorphin-2, deltorphin II and their analogs suppress formalin-induced nociception and c-Fos expression in the rat spinal cord. Life Sci 73:403-412.

Lao LJ, Song B, Marvizón JC (2003) Neurokinin release produced by capsaicin acting on the central terminals and axons of primary afferents: relationship with $\mathrm{N}$-methyl-D-aspartate and $\mathrm{GABA}_{\mathrm{B}}$ receptors. Neuroscience 121:667-680.

Ma J, Zhang Y, Kalyuzhny AE, Pan ZZ (2006) Emergence of functional $\delta$-opioid receptors induced by chronic morphine. Mol Pharmacol 69:1137-1145.

Madziva MT, Edwardson JM (2001) Trafficking of green fluorescent protein-tagged muscarinic M4 receptors in NG108-15 cells. Eur J Pharmacol 428:9-18.

Mantyh PW, DeMaster E, Malhotra A, Ghilardi JR, Rogers SD, Mantyh CR, Liu H, Basbaum AI, Vigna SR, Maggio JE (1995) Receptor endocytosis and dendrite reshaping in spinal neurons after somatosensory stimulation. Science 268:1629-1632.

Martin M, Matifas A, Maldonado R, Kieffer BL (2003) Acute antinociceptive responses in single and combinatorial opioid receptor knockout mice: distinct mu, delta and kappa tones. Eur J Neurosci 17:701-708.

Marvizón JC, Wang X, Matsuka Y, Neubert JK, Spigelman I (2003) Relationship between capsaicin-evoked substance $\mathrm{P}$ release and neurokinin 1 receptor internalization in the rat spinal cord. Neuroscience 118:535-545.

Matta JA, Cornett PM, Miyares RL, Abe K, Sahibzada N, Ahern GP (2008) General anesthetics activate a nociceptive ion channel to enhance pain and inflammation. Proc Natl Acad Sci U S A 105:8784-8789.

McDonald NA, Henstridge CM, Connolly CN, Irving AJ (2007) Generation and functional characterization of fluorescent, N-terminally tagged CB1 receptor chimeras for live-cell imaging. Mol Cell Neurosci 35:237-248.

McLean AJ, Milligan G (2000) Ligand regulation of green fluorescent protein-tagged forms of the human $\beta_{1}$ - and $\beta_{2}$-adrenoceptors; comparisons with the unmodified receptors. Br J Pharmacol 130:1825-1832.

McNamara CR, Mandel-Brehm J, Bautista DM, Siemens J, Deranian KL, Zhao M, Hayward NJ, Chong JA, Julius D, Moran MM, Fanger CM (2007) TRPA1 mediates formalin-induced pain. Proc Natl Acad Sci U S A 104:13525-13530.

Mennicken F, Zhang J, Hoffert C, Ahmad S, Beaudet A, O'Donnell D (2003) Phylogenetic changes in the expression of delta opioid receptors in spinal cord and dorsal root ganglia. J Comp Neurol 465:349-360.

Minami M, Maekawa K, Yabuuchi K, Satoh M (1995) Double in situ hybridization study on coexistence of mu-, delta- and kappa-opioid receptor mRNAs with preprotachykinin A mRNA in the rat dorsal root ganglia. Brain Res Mol Brain Res 30:203-210.

Molander C, Xu Q, Grant G (1984) The cytoarchitectonic organization of the spinal cord in the rat. I. The lower thoracic and lumbosacral cord. J Comp Neurol 230:133-141.

Morinville A, Cahill CM, Esdaile MJ, Aibak H, Collier B, Kieffer BL, Beaudet A (2003) Regulation of $\delta$-opioid receptor trafficking via $\mu$-opioid receptor stimulation: evidence from $\mu$-opioid receptor knock-out mice. J Neurosci 23:4888-4898.

Morinville A, Cahill CM, Kieffer B, Collier B, Beaudet A (2004a) Mu-opioid receptor knockout prevents changes in delta-opioid receptor trafficking induced by chronic inflammatory pain. Pain 109:266-273.

Morinville A, Cahill CM, Aibak H, Rymar VV, Pradhan A, Hoffert C, Mennicken F, Stroh T, Sadikot AF, O’Donnell D, Clarke PB, Collier B, Henry JL, Vincent JP, Beaudet A (2004b) Morphine-induced changes in $\delta$-opioid receptor trafficking are linked to somatosensory processing in the rat spinal cord. J Neurosci 24:5549-5559.

Murray CW, Cowan A (1991) Tonic pain perception in the mouse: differential modulation by three receptor-selective opioid agonists. J Pharmacol Exp Ther 257:335-341.

Nazarian A, Gu G, Gracias NG, Wilkinson K, Hua XY, Vasko MR, Yaksh TL (2008) Spinal $N$-methyl-D-aspartate receptors and nociception-evoked release of primary afferent substance P. Neuroscience 152:119-127.

Nishiyama T (2000) Interaction between intrathecal morphine and glutamate receptor antagonists in formalin test. Eur J Pharmacol 395:203-210.
Ossipov MH, Kovelowski CJ, Wheeler-Aceto H, Cowan A, Hunter JC, Lai J, Malan TP Jr, Porreca F (1996) Opioid antagonists and antisera to endogenous opioids increase the nociceptive response to formalin: demonstration of an opioid kappa and delta inhibitory tone. J Pharmacol Exp Ther 277:784-788.

Overland AC, Kitto KF, Chabot-Doré AJ, Rothwell PE, Fairbanks CA, Stone LS, Wilcox GL (2009) Protein kinase C mediates the synergistic interaction between agonists acting at $\alpha 2$-adrenergic and $\delta$-opioid receptors in spinal cord. J Neurosci 29:13264-13273.

Riedl MS, Schnell SA, Overland AC, Chabot-Doré AJ, Taylor AM, Ribeiroda-Silva A, Elde RP, Wilcox GL, Stone LS (2009) Coexpression of alpha $2 \mathrm{~A}$-adrenergic and delta-opioid receptors in substance P-containing terminals in rat dorsal horn. J Comp Neurol 513:385-398.

Roy S, Rached M, Gallo-Payet N (2007) Differential regulation of the human adrenocorticotropin receptor [melanocortin-2 receptor (MC2R)] by human MC2R accessory protein isoforms alpha and beta in isogenic human embryonic kidney 293 cells. Mol Endocrinol 21:1656-1669.

Sawynok J, Reid A, Meisner J (2006) Pain behaviors produced by capsaicin: influence of inflammatory mediators and nerve injury. J Pain 7:134-141.

Scherrer G, Befort K, Contet C, Becker J, Matifas A, Kieffer BL (2004) The delta agonists DPDPE and deltorphin II recruit predominantly mu receptors to produce thermal analgesia: a parallel study of mu, delta and combinatorial opioid receptor knockout mice. Eur J Neurosci 19:2239-2248.

Scherrer G, Imamachi N, Cao YQ, Contet C, Mennicken F, O’Donnell D, Kieffer BL, Basbaum AI (2009) Dissociation of the opioid receptor mechanisms that control mechanical and heat pain. Cell 137:1148-1159.

Song B, Marvizón JC (2003) Dorsal horn neurons firing at high frequency, but not primary afferents, release opioid peptides that produce micro-opioid receptor internalization in the rat spinal cord. J Neurosci 23:9171-9184.

Spike RC, Puskár Z, Sakamoto H, Stewart W, Watt C, Todd AJ (2002) MOR-1-immunoreactive neurons in the dorsal horn of the rat spinal cord: evidence for nonsynaptic innervation by substance P-containing primary afferents and for selective activation by noxious thermal stimuli. Eur J Neurosci 15:1306-1316.

Tao YX, Zhao ZQ (1997) Ultrastructure of Fos-labeled neurons relating to nociceptive primary afferent and substance $P$ terminals in rat spinal superficial laminae. Neuropeptides 31:327-332.

Tao YX, Wei F, Zhao ZQ (1997) A contribution of neurokinin-1 receptor to formalin-induced c-fos expression in the rat spinal dorsal horn. Neurosci Lett 221:105-108.

Tjølsen A, Berge OG, Hunskaar S, Rosland JH, Hole K (1992) The formalin test: an evaluation of the method. Pain 51:5-17.

Todd AJ, Puskar Z, Spike RC, Hughes C, Watt C, Forrest L (2002) Projection neurons in lamina I of rat spinal cord with the neurokinin 1 receptor are selectively innervated by substance P-containing afferents and respond to noxious stimulation. J Neurosci 22:4103-4113.

van Rijn RM, Whistler JL, Waldhoer M (2010) Opioid-receptor-heteromerspecific trafficking and pharmacology. Curr Opin Pharmacol 10:73-79.

Wang HB, Guan JS, Bao L, Zhang X (2008) Distinct subcellular distribution of delta-opioid receptor fused with various tags in PC12 cells. Neurochem Res 33:2028-2034.

Wang HB, Zhao B, Zhong YQ, Li KC, Li ZY, Wang Q, Lu YJ, Zhang ZN, He SQ, Zheng HC, Wu SX, Hökfelt TG, Bao L, Zhang X (2010) Coexpression of delta- and mu-opioid receptors in nociceptive sensory neurons. Proc Natl Acad Sci U S A 107:13117-13122.

Watanabe H, Nakayama D, Yuhki M, Sawai T, Sakurada W, Katsuyama S, Hayashi T, Watanabe C, Mizoguchi H, Fujimura T, Sakurada T, Sakurada S (2006) Differential inhibitory effects of mu-opioids on substance P- and capsaicin-induced nociceptive behavior in mice. Peptides 27:760-768.

Williams S, Evan GI, Hunt SP (1990) Changing patterns of c-fos induction in spinal neurons following thermal cutaneous stimulation in the rat. Neuroscience 36:73-81.

Zhang X, Bao L, Guan JS (2006) Role of delivery and trafficking of deltaopioid peptide receptors in opioid analgesia and tolerance. Trends Pharmacol Sci 27:324-329.

Zhao B, Wang HB, Lu YJ, Hu JW, Bao L, Zhang X (2011) Transport of receptors, receptor signaling complexes and ion channels via neuropeptide-secretory vesicles. Cell Res 21:741-753.

Zimmer A, Zimmer AM, Baffi J, Usdin T, Reynolds K, König M, Palkovits M, Mezey E (1998) Hypoalgesia in mice with a targeted deletion of the tachykinin 1 gene. Proc Natl Acad Sci U S A 95:2630-2635. 